\title{
Effects of temperature on wastewater treatment in an affordable microbial fuel cell-adsorption hybrid system
}

\author{
Pei-Fang Tee ${ }^{\mathrm{a}}$, Mohammad Omar Abdullah ${ }^{\mathrm{a}, *}$, Ivy A.W. Tan ${ }^{\mathrm{a}}$, Mohamed A.M. Amin ${ }^{\mathrm{a}}$, \\ Cirilo Nolasco-Hipolito ${ }^{\mathrm{a}}$, Kopli Bujang ${ }^{\mathrm{b}}$ \\ a Department of Chemical Engineering and Energy Sustainability, Faculty of Engineering, Universiti Malaysia Sarawak (UNIMAS), 94300, Kota Samarahan, \\ Sarawak, Malaysia \\ ${ }^{\mathrm{b}}$ Faculty of Resource Science E Technology, Universiti Malaysia Sarawak (UNIMAS), 94300, Kota Samarahan, Sarawak, Malaysia
}

\section{A R T I C L E I N F O}

\section{Article history:}

Received 5 September 2016

Received in revised form 25 November 2016

Accepted 27 November 2016

Available online 27 November 2016

\section{Keywords:}

Temperature effect

Hybrid microbial fuel cell

Adsorption

Bio-energy generation

Wastewater treatment

\begin{abstract}
A B S T R A C T
A cost effective single-chamber microbial fuel cell (MFC) integrated with adsorption system was tested under different operating temperatures to observe $\mathrm{pH}$ profiles, organics, solids, nutrients, color and turbidity removal and power density generation. The optimum operating temperature range was found to be $\sim 25-35^{\circ} \mathrm{C}$ with majority of the removals achieved at $\sim 35^{\circ} \mathrm{C}$. Maximum power density recorded was $74 \pm 6 \mathrm{~mW} / \mathrm{m}^{3}$ with coulombic efficiency (CE) of $10.65 \pm 0.5 \%$ when operated at $35^{\circ} \mathrm{C}$. Present studies had successfully demonstrated the effectiveness of a hybrid system in removing various types of pollutants in POME at optimum temperature and able to fulfill the stringent effluent discharge limit. Chemical oxygen demand (COD), total solids (TS) and turbidity removals increase linearly with temperatures with removal efficiency of $0.5889 \% \mathrm{C}^{-1}, 1.0754 \% \mathrm{C}^{-1}$ and $0.7761 \% \mathrm{C}^{-1}$, respectively. The temperature coefficient $\left(Q_{10}\right)$ is found to be $1.06,1.45$ and 1.09 , respectively. Besides, MFC-adsorption hybrid system had demonstrated superior stability over a wide range of operating temperatures in terms of COD removal as compared to the non-integrated MFC system.
\end{abstract}

(c) 2016 Elsevier Ltd. All rights reserved.

\section{Introduction}

Microbial fuel cells (MFCs) are bioelectrochemical devices that utilize bacteria as a biocatalyst to oxidize the organic matters present in the wastewater to produce bioenergy [1-3]. MFCs have the ability to remove various types of pollutants present in the wastewater [4,5]. They are renowned for their great capability for direct bio-energy generation from various biodegradable compounds, ranging from pure compounds to complex substrates in the wastewater [6]. There were many studies done on the typical standalone two-chambered MFC because such design is very easily constructed and typically suitable for lab scale studies. Nevertheless, standalone treatment system has limitation such as less wastewater treatment efficiency as compared to the MFC hybrid system [7]. Much studies had demonstrated the ability of hybrid MFCs in removing various types of pollutants present in the wastewater such as chemical oxygen demand (COD) [8-10], phosphorus [11], dye [12,13], suspended solids (SS) [10], total

\footnotetext{
* Corresponding author.

E-mail addresses: amomar13@gmail.com, amomar@feng.unimas.my, amomar@unimas.my (M.O. Abdullah).
}

nitrogen (TN) [14], ammonia nitrogen $\left(\mathrm{NH}_{3}-\mathrm{N}\right)[15,16]$, and so on. Majority of the effective pollutants removal were done by integrating MFC with other unit operation or processes. Recently, it has been reported that greater bio-energy generation and wastewater treatment can be accomplished when MFC is hybridized with unit operations or processes such as adsorption [17], membrane bioreactor [10], sequencing batch reactor [18], membrane, aeration system [19], anaerobic digester [20], aerobic system [15], biofermentor [21], anaerobic fluidized bed [22], wetland [23], anaerobic fluidized membrane reactor [24] and anaerobic sludge blanket [25]. MFC could also possibly be combined with other process such as nitritation-anammox where the research had been greatly developing in order to remove wastewater which content high level of nitrogen content $[26,27]$.

Now, among many influencing parameters, temperature is one of the important factors which can affect the power generation as well as the water treatment performance. The definite temperature may affect the bacterial kinetics and also the types of bacteria that reside in the anodic biofilms in the wastewater fed systems [28]. Thus, while bacterial growth rate and respiration can be affected by the changes in temperature, the community development and structure can also be crucial [29]. 


\begin{tabular}{|c|c|}
\hline \multicolumn{2}{|c|}{ Nomenclature } \\
\hline ACFF & Activated carbon fiber felt \\
\hline AFMBR & Anaerobic fluidized bed membrane bioreactor \\
\hline APHA & American public health association \\
\hline BOD & Biochemical oxygen demand \\
\hline $\mathrm{C}_{a}$ & $\begin{array}{l}\text { Total coulombs by calculated by integrating current } \\
\text { over time }\end{array}$ \\
\hline CE & Coulombic efficiency \\
\hline COD & Chemical oxygen demand \\
\hline $\mathrm{C}_{t}$ & Concentration of the solution at any time \\
\hline $\mathrm{D}_{1}$ & Design of Behera et al. (2011) \\
\hline DOE & Department of environment Malaysia \\
\hline ECG & Electrocardiogram \\
\hline GAC & Granular activated carbon \\
\hline GFB & Graphite fiber brush \\
\hline I & Current (A) \\
\hline I-BAF & Immobilized biological aerated filter \\
\hline MFC & Microbial fuel cell \\
\hline MBR & Membrane bioreactor \\
\hline $\mathrm{NH} 4^{+}$ & Ammonium ion \\
\hline $\mathrm{NH}_{3}-\mathrm{N}$ & Ammonia nitrogen \\
\hline $\mathrm{P}$ & Power density $\left(\mathrm{mW} / \mathrm{m}^{3}\right)$ \\
\hline PEM & Proton exchange membrane \\
\hline POME & Palm oil mill effluent \\
\hline $\mathrm{Pt}$ & Platinum \\
\hline $\mathrm{Q}_{10}$ & Temperature coefficient \\
\hline $\mathrm{R}_{1}$ & Rate at temperature 1 \\
\hline $\mathrm{R}_{2}$ & Rate at temperature 2 \\
\hline SS & Suspended solids \\
\hline $\mathrm{T}_{1}$ & Temperature 1 \\
\hline $\mathrm{T}_{2}$ & Temperature 2 \\
\hline TN & Total nitrogen \\
\hline TMBR & Tubular membrane bioreactor \\
\hline TOC & Total organic carbon \\
\hline TSS & Total suspended solids \\
\hline TVS & Total volatile solids \\
\hline V & Voltage (V) \\
\hline$v$ & Liquid volume (L) \\
\hline
\end{tabular}

Thus far, not much research has been done on the air- cathode MFC with ceramic pot as the substitute to proton exchange membrane (PEM) except Ghadge \& Ghangrekar [30] and Chatterjee and Ghangrekar et al. [31]. The reactor setups for both studies were done on standalone MFC and recently, only one had come to the effort of integrating MFC with adsorption hybrid system with ceramic pot as the PEM [32]. Besides, the effects of temperature in MFC hybrid system has never been understood especially when activated carbon is applied in the design because the performance of both MFC and adsorption system are sensitive to operating temperatures.

A recent study has been done by integrating MFC with adsorption system and such system has demonstrated great pollutants removal in the palm oil mill effluent (POME) such as COD, biochemical oxygen demand (BOD), total organic carbon (TOC), TN, $\mathrm{NH}_{3}-\mathrm{N}$, total solids (TS), total suspended solids (TSS), total volatile solids (TVS), turbidity and color [32]. Till now, the study of such system was only done at operating temperature of $25 \pm 1{ }^{\circ} \mathrm{C}$. The effect of other operating temperature for such system has not been studied in terms of wastewater treatment and bio-energy generation.

MFCs can produce energy from various substrates and reported in literature. However, to the best knowledge of the authors, the studies of the effect of temperatures had only been done on these few sources which includes beer brewery wastewater [33], domestic wastewater [34-36], sanitary wastewater [37], barley processing wastewater [38] and synthetic wastewater [39,40]. Municipal water treatment experiments which were done previously at low temperatures $\left(5-15^{\circ} \mathrm{C}\right)$ could also be used as a source of high potential MFC operation for electricity generation [41]. At present, none has come to understand the effects of temperature with palm oil mill effluent (POME) as a substrate to MFC which is known as the major contributor of the pollution loads in the rivers in countries such as Malaysia and Indonesia. POME is very rich in terms of organic matters and existing treatment method such as ponding system requires long retention time and ineffective to meet the wastewater quality standard. Since POME has very high organic matters content, therefore it can be used as a source of fuel to the MFC for bioenergy generation.

The aim of this work was to treat the palm oil mill effluent and at the same time to take the advantage from the treatment by integrating the MFC with adsorption system to generate bioenergy. Thus, the effects of temperatures in terms of power generation, $\mathrm{pH}$ profiles, organics, solids, nutrients, color and turbidity removal in the MFC-adsorption hybrid system were carried out systematically and presented in the present study.

\section{Experimental}

\subsection{MFC construction}

The single chamber air-cathode MFC-adsorption hybrid system with the separator fabricated from ceramic material were constructed and described in Ref. [32]. The schematic diagram of the MFC-adsorption hybrid system and the membrane electrode assembly are as shown in Fig. 1. Anode compartment consists of graphite fiber brush (GFB) (Mill-Rose Co., USA) that served as current collector and employing commercial granular activated carbon (GAC). Prior to experiment, the GFB was soaked in pure acetone overnight and heat-treated at $450^{\circ} \mathrm{C}$, and washed three times with distilled water. GAC was cleaned with distilled water several times and oven dried to remove ashes and other impurities before they were used. A specific surface area of $1000 \mathrm{~m}^{2} \mathrm{~g}^{-1}$ (Nantong Ruibang Activated Carbon Filter Material Co. Ltd, China) activated carbon fiber felt (ACFF) was selected as the cathodes materials, which were wrapped around the ceramic pot $(7 \mathrm{~mm}$ thick) which acted as the medium for proton exchange. Electrocardiogram (ECG) gel was applied evenly between ceramic pot and ACFF in order to increase hydration and contact area. A copper rod was selected as the circuit connector in the cathode compartment. The reactor working volume for this setup was $5.65 \mathrm{~L}$.

\subsection{Experimental design and operation}

The MFC-adsorption hybrid system was inoculated with POME from nearby palm oil mill at Felcra Jaya, Kota Samarahan where the POME samples was taken from the second anaerobic pond and the same source was used as the substrate to the MFCs without any additions of nutrient and buffer solution for the anode chamber. Wastewater sample was kept in a cold room at $3^{\circ} \mathrm{C}$ prior to use. The characteristic of the POME collected was analyzed and tested (Table 1).

The MFC-adsorption hybrid systems were inoculated at $25 \pm 1{ }^{\circ} \mathrm{C}$, where $50 \Omega$ of external resistance was installed in between the anode and the cathode segment. The systems were operated at various temperature $\left(15^{\circ} \mathrm{C}, 20^{\circ} \mathrm{C}, 30^{\circ} \mathrm{C}, 35^{\circ} \mathrm{C}, 40^{\circ} \mathrm{C}\right.$ and $55^{\circ} \mathrm{C}$ ) once steady voltage was achieved and the performance were compared to the previous study which was done at operating temperature of $25^{\circ} \mathrm{C}$ [32]. The performance of the MFCs at 


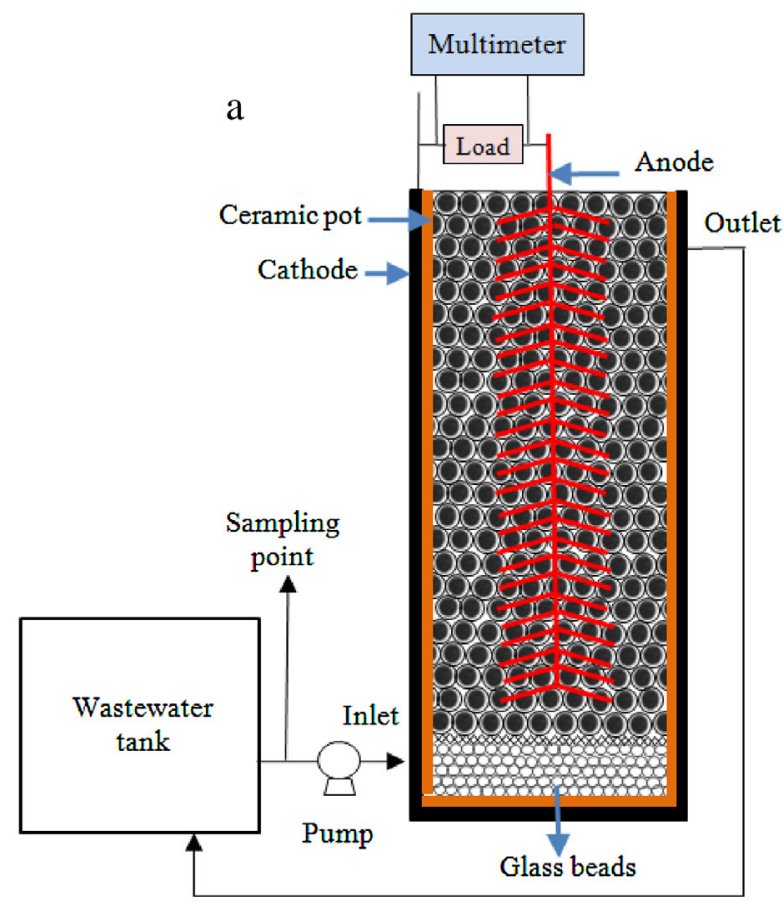

$\mathrm{b}$

Copper rod

(cathode)

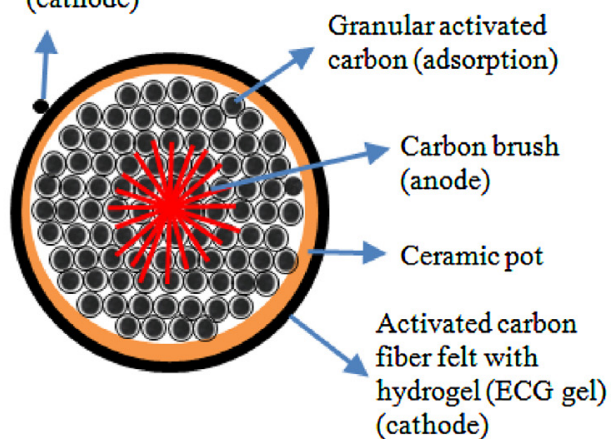

Fig. 1. (a) Schematic diagram of the (a) MFC-adsorption hybrid system (front view) and (b) membrane electrode assembly (top view).

Table 1

Characteristic of POME after the second anaerobic pond with the discharge standards as per Malaysian Department of Environment, DOE.

\begin{tabular}{llll}
\hline Parameter & Concentration & Unit & Limit \\
\hline $\mathrm{pH}$ & $7.85 \pm 0.2$ & - & $5-9$ \\
$\mathrm{COD}$ & $884 \pm 3$ & $\mathrm{mg} / \mathrm{l}$ & $\mathrm{a}$ \\
$\mathrm{BOD}_{3}$ & $233 \pm 2$ & $\mathrm{mg} / \mathrm{l}$ & $100(20)$ \\
$\mathrm{TS}$ & $6860 \pm 3$ & $\mathrm{mg} / \mathrm{l}$ & $\mathrm{a}$ \\
$\mathrm{TSS}$ & $539 \pm 3$ & $\mathrm{mg} / \mathrm{l}$ & 400 \\
Turbidity & $203 \pm 2$ & $\mathrm{NTU}$ & $\mathrm{a}$ \\
TOC & $429.5 \pm 2$ & $\mathrm{mg} / \mathrm{l}$ & $\mathrm{a}$ \\
$\mathrm{TVS}$ & $1350 \pm 2$ & $\mathrm{mg} / \mathrm{l}$ & $\mathrm{a}$ \\
Color & $9017 \pm 2$ & $\mathrm{Pt}-\mathrm{Co}$ & $\mathrm{a}$ \\
TN & $167.4 \pm 2$ & $\mathrm{mg} / \mathrm{l}$ & 200 \\
$\mathrm{NH}_{3}-\mathrm{N}$ & $121 \pm 2$ & $\mathrm{mg} / \mathrm{l}$ & 150 \\
\hline
\end{tabular}

${ }^{\mathrm{a}}$ No discharge standard.

different temperatures was tested in parallel on individual MFCs in the closed-loop mode with fresh POME using incubators (146E, Fisher Scientific). For each temperature settings, the experiments were replicated with fresh loads of GAC.

\subsection{Measurement and analysis}

The $\mathrm{pH}$ was measured using a digital $\mathrm{pH}$ meter (PCSTestr 35, Eutech). COD were conducted according to HACH method 8000 which complied to the APHA standard methods with DR900 (Hach). $\mathrm{BOD}_{3}$ were carried out according to Department of Environment (DOE), Malaysia 2011 reference method where BOD was carried out for three days at $30^{\circ} \mathrm{C}$. TS, TSS and TVS tests were implemented according to the APHA standard methods with APHA 2540 B, APHA 2540 D and APHA 2540 E, respectively. Turbidity was measured using a turbidity meter, TN-100/T-100 (Eutech) and TOC by using a TOC analyzer, TOC-LCPH (Shimadzu). Color was conducted according to HACH method 8025 which complied to the APHA standard methods with DR900 (Hach). TN was carried out according to the APHA 4500-Norg B method whereas $\mathrm{NH}_{3}-\mathrm{N}$ was conducted as per $\mathrm{HACH}$ method 8038 with
DR5000 (Hach). Experiments for each different condition were replicated twice. The wastewater samples were taken on daily basis until equilibrium was achieved and the characterization were done in triplicate for each sample obtained from the MFCs including the replicated systems. The average and standard deviation of the data for each parameter were then calculated and presented.

Voltage was continuously monitored and measured every hourly using a multimeter with data logger system (Fluke 287/ 289).). Polarization data were collected by varying the external resistance (varied from $100 \mathrm{~K} \Omega$ to $10 \Omega$ ) with a variable resistance box (Tenma 72-7270) when the power production was stable.

Power density, $P\left(\mathrm{~mW} \mathrm{~m}^{-3}\right)$ was calculated by

$P=I V / \nu$

where $I$ is the current, $V$ is the voltage, and $v$ is the liquid working volume in the anode compartment.

The Coulombic efficiency (CE) is described as the percentage of electrons recovered from organic matter versus the theoretical maximum whereby all electrons are used for electricity production. CE was calculated by

$C E(\%)=C_{a} / C_{t} \times 100$

where $C_{a}$ is the total coulombs calculated by integrating the current over time, $C_{t}$ is the theoretical amount of coulombs available from the oxidation of POME.

\section{Results and discussion}

\section{1. $\mathrm{pH}$ profiles}

The $\mathrm{pH}$ of the substrate inside the MFC-adsorption hybrid system was measured when the system was ready to be operated in the closed-loop mode. The pH was measured at the beginning of the experiment for all the MFCs operated at different operating temperature and also throughout the operation until equilibrium was achieved. Three different trends can be observed during the first $19 \mathrm{~h}$ : the temperatures of $15^{\circ} \mathrm{C}, 20^{\circ} \mathrm{C}, 40^{\circ} \mathrm{C}$ and $55^{\circ} \mathrm{C}$ are 
under one similar trend; $25^{\circ} \mathrm{C}$ under second trend; while $30^{\circ} \mathrm{C}$ and $35^{\circ} \mathrm{C}$ under another trend. At this point, the MFCs operated at the first trend temperatures had initial $\mathrm{pH}$ ranging in between $8.02 \pm 0.1$ and $8.31 \pm 0.1$. In the subsequent $19 \mathrm{~h}$ of operation, the $\mathrm{pH}$ profile dropped to $\mathrm{pH}$ ranging in between $7.38 \pm 0.1$ and $7.63 \pm 0.2$ before going up again and settled at $\mathrm{pH} 8.07,8.36,8.25$ and 8.35 for MFCs operated at $15^{\circ} \mathrm{C}, 20^{\circ} \mathrm{C}, 40^{\circ} \mathrm{C}$ and $55^{\circ} \mathrm{C}$, respectively. When the operating temperature of the MFC was $25^{\circ} \mathrm{C}$, the corresponding $\mathrm{pH}$ was found to be $7.85 \pm 0.2$ and $7.08 \pm 0.3$ at the beginning and at the end of experiment, respectively and the $\mathrm{pH}$ decreased to $6.98 \pm 0.2$ in the first $19 \mathrm{~h}$ of operation. MFCs operated at $30^{\circ} \mathrm{C}$ and $35^{\circ} \mathrm{C}$ having almost similar pH profile with initial $\mathrm{pH}$ of $8.02 \pm 0.2$ and $8.07 \pm 0.1$ which settled at $7.40 \pm 0.2$ and $7.55 \pm 0.2$ with a pH drop of $0.62 \pm 0.1$ and $0.52 \pm 0.1$, respectively during the first $19 \mathrm{~h}$ of operation.

Generally from the lower part of the microcosm, organic matter found in the wastewater might had been oxidized into fatty acids under the anaerobic condition which shifted the $\mathrm{pH}$ towards the acidic side. With the absence of oxygen in the MFCs, pHs tend to be decreased due to the biodegradation of the organic matter in the wastewater in order to produce fatty acids [42]. Thus, this scenario explained the great fall of $\mathrm{pH}$ in the first $19 \mathrm{~h}$ of operation in MFCs operated at $30^{\circ} \mathrm{C}$ and $35^{\circ} \mathrm{C}$, where the increase in microbial

Table 2

Pollutants removal efficiency under various operating conditions in between MFC-adsorption hybrid system and other MFCs.

\begin{tabular}{|c|c|c|c|c|}
\hline \multirow[t]{2}{*}{ Parameter } & \multirow{2}{*}{$\begin{array}{l}\text { MFC-adsorption hybrid (Present study) } \\
\% \text { removal }\end{array}$} & \multirow[t]{2}{*}{ MFC-adsorption hybrid [32] } & \multicolumn{2}{|l|}{ Other MFC systems } \\
\hline & & & \% removal & Refs. \\
\hline COD & $\begin{array}{l}15^{\circ} \mathrm{C}-82.5 \pm 0.3 \% \\
20^{\circ} \mathrm{C}-84.2 \pm 0.5 \% \\
30^{\circ} \mathrm{C}-91.6 \pm 0.8 \% \\
35^{\circ} \mathrm{C}-93.5 \pm 0.6 \% \\
40^{\circ} \mathrm{C}-83.1 \pm 0.5 \% \\
55^{\circ} \mathrm{C}-79.2 \pm 0.4 \%\end{array}$ & $25^{\circ} \mathrm{C}-90.5 \pm 0.3 \%$ & $\begin{array}{l}20^{\circ} \mathrm{C}-62 \% \\
35^{\circ} \mathrm{C}-84 \% \\
40^{\circ} \mathrm{C}-84 \% \\
55^{\circ} \mathrm{C}-58.8 \% \\
30^{\circ} \mathrm{C}-29.49 \%\end{array}$ & $\begin{array}{l}{[43]} \\
{[44]}\end{array}$ \\
\hline BOD & $\begin{array}{l}15^{\circ} \mathrm{C}-80.69 \pm 0.4 \% \\
20^{\circ} \mathrm{C}-85.0 \pm 0.3 \% \\
30^{\circ} \mathrm{C}-94.4 \pm 0.5 \% \\
35^{\circ} \mathrm{C}-95.0 \pm 0.3 \% \\
40^{\circ} \mathrm{C}-85.10 \pm 0.6 \% \\
55^{\circ} \mathrm{C}-83.34 \pm 0.4 \%\end{array}$ & $25^{\circ} \mathrm{C}-93.1 \pm 0.5 \%$ & 77\% (temperature not mentioned) & {$[45]$} \\
\hline TOC & $100 \%$ for all the temperatures & $25^{\circ} \mathrm{C}-100 \%$ & $\begin{array}{l}85 \% \text { (temperature not mentioned) } \\
25^{\circ} \mathrm{C}-75 \pm 2 \% \\
30{ }^{\circ} \mathrm{C}-22.82 \%\end{array}$ & $\begin{array}{l}{[46]} \\
{[47]} \\
{[44]}\end{array}$ \\
\hline TS & $\begin{array}{l}15^{\circ} \mathrm{C}-19.9 \pm 0.5 \% \\
20^{\circ} \mathrm{C}-27.9 \pm 0.8 \% \\
30^{\circ} \mathrm{C}-38.5 \pm 0.8 \% \\
35^{\circ} \mathrm{C}-41.4 \pm 0.4 \% \\
40^{\circ} \mathrm{C}-34.0 \pm 0.5 \% \\
55^{\circ} \mathrm{C}-29.9 \pm 0.8 \%\end{array}$ & $25^{\circ} \mathrm{C}-35.0 \pm 0.3 \%$ & & \\
\hline TSS & $\begin{array}{l}15^{\circ} \mathrm{C}-82.3 \pm 0.6 \% \\
20^{\circ} \mathrm{C}-88.7 \pm 1.2 \% \\
30^{\circ} \mathrm{C}-97.7 \pm 1.0 \% \\
35^{\circ} \mathrm{C}-98.0 \pm 0.6 \% \\
40^{\circ} \mathrm{C}-88.8 \pm 0.7 \% \\
55^{\circ} \mathrm{C}-83.65 \pm 0.9 \%\end{array}$ & $25^{\circ} \mathrm{C}-96.9 \pm 0.2 \%$ & $\begin{array}{l}\text { ambient }-86.3 \% \\
100 \% \text { (temperature not mentioned) }\end{array}$ & $\begin{array}{l}{[48]} \\
{[9]}\end{array}$ \\
\hline TVS & $\begin{array}{l}15^{\circ} \mathrm{C}-65.7 \pm 0.6 \% \\
20^{\circ} \mathrm{C}-76.6 \pm 0.5 \% \\
30^{\circ} \mathrm{C}-90.7 \pm 0.4 \% \\
35^{\circ} \mathrm{C}-89.5 \pm 0.6 \% \\
40^{\circ} \mathrm{C}-71.8 \pm 0.5 \% \\
55^{\circ} \mathrm{C}-65.9 \pm 0.3 \%\end{array}$ & $25^{\circ} \mathrm{C}-89.0 \pm 0.2 \%$ & - & - \\
\hline Color & $\begin{array}{l}15^{\circ} \mathrm{C}-92.0 \pm 0.7 \% \\
20^{\circ} \mathrm{C}-95.3 \pm 0.8 \% \\
30^{\circ} \mathrm{C}-96.0 \pm 0.7 \% \\
35^{\circ} \mathrm{C}-94.0 \pm 0.3 \% \\
40^{\circ} \mathrm{C}-91.0 \pm 0.6 \% \\
55^{\circ} \mathrm{C}-90.0 \pm 0.5 \%\end{array}$ & $25^{\circ} \mathrm{C}-98.1 \pm 0.3 \%$ & $\begin{array}{l}29 \pm 2{ }^{\circ} \mathrm{C}-31.67 \% \\
30^{\circ} \mathrm{C}-34.16 \%\end{array}$ & $\begin{array}{l}{[52]} \\
{[44]}\end{array}$ \\
\hline Turbidity & $\begin{array}{l}15^{\circ} \mathrm{C}-86.6 \pm 0.4 \% \\
20^{\circ} \mathrm{C}-91.5 \pm 0.8 \% \\
30^{\circ} \mathrm{C}-98.00 \pm 0.7 \\
35^{\circ} \mathrm{C}-93.2 \pm 0.5 \% \\
40^{\circ} \mathrm{C}-81.3 \pm 0.6 \% \\
55^{\circ} \mathrm{C}-78.2 \pm 0.3 \%\end{array}$ & $25^{\circ} \mathrm{C}-96.0 \pm 0.4 \%$ & $28 \pm 2{ }^{\circ} \mathrm{C}-96 \%$ & {$[53]$} \\
\hline $\mathrm{NH}_{3}-\mathrm{N}$ & $\begin{array}{l}15^{\circ} \mathrm{C}-0 \% \\
20^{\circ} \mathrm{C}-63.5 \pm 0.6 \% \\
30^{\circ} \mathrm{C}-92.4 \pm 0.4 \% \\
35^{\circ} \mathrm{C}-93.3 \pm 0.8 \% \\
40^{\circ} \mathrm{C}-64.0 \pm 0.5 \% \\
55^{\circ} \mathrm{C}-0 \%\end{array}$ & $25^{\circ} \mathrm{C}-89.6 \pm 0.5 \%$ & $\begin{array}{l}23^{\circ} \mathrm{C}-30.4 \% \\
76 \% \text { (Room temperature) }\end{array}$ & $\begin{array}{l}{[54]} \\
{[25]}\end{array}$ \\
\hline TN & $\begin{array}{l}15^{\circ} \mathrm{C}-0 \% \\
20^{\circ} \mathrm{C}-52.6 \pm 0.8 \% \\
30^{\circ} \mathrm{C}-98.00 \pm 0.7 \% \\
35^{\circ} \mathrm{C}-87.3 \pm 0.7 \% \\
40^{\circ} \mathrm{C}-48.0 \pm 0.9 \% \\
55^{\circ} \mathrm{C}-0 \%\end{array}$ & $25^{\circ} \mathrm{C}-84.3 \pm 0.4 \%$ & - & - \\
\hline
\end{tabular}


activities under these temperatures would tend to generate more fatty acids.

In comparison to the $\mathrm{pH}$ profiles in a non-hybrid dual chamber MFC done in the previous study, similar trend can be observed when operated in the range of $8-22^{\circ} \mathrm{C}$ and $20-35^{\circ} \mathrm{C}$ where the $\mathrm{pH}$ of the fresh feed ( $\mathrm{pH} 7.4$ ) reached the minimum value of about 6.2 and 6.7, respectively after operated for $20-25 \mathrm{~h}$ before the $\mathrm{pH}$ started to move up slowly and finally became almost constant [39]. Nevertheless, it is very difficult to compare this performance with the current study because the previous study was done in a wide range of operating temperatures whereas in the current study, the pH profiles was obtained at each specific operating temperatures. Besides, the $\mathrm{pH}$ profiles were not reported in the previous study for MFC operated at thermophilic temperatures $\left(>40^{\circ} \mathrm{C}\right)$.

\subsection{Organics and solids removal}

The results for all the pollutants removal efficiency under various operating conditions in between MFC-adsorption hybrid system and other MFCs were summarized in Table 2. In the previous study, MFC-adsorption hybrid system operated at $25^{\circ} \mathrm{C}$ had recorded COD reduction of $90.5 \pm 0.3 \%$ [32]. The performance of the COD and BOD removal percentage at various operating temperature were carried out in the present study and results were as shown in Fig. 2a. The optimum COD removal percentage was found to be at $35^{\circ} \mathrm{C}$, followed by $30^{\circ} \mathrm{C}$ with the maximum removal of $93.5 \pm 0.6 \%$ and $91.6 \pm 0.8 \%$, respectively. COD removal percentage at thermophilic temperatures $\left(>40^{\circ} \mathrm{C}\right)$ were $10.43 \pm 0.2 \%$ and $14.37 \pm 0.3 \%$ lower as compared to the performance at optimum temperature with removal percentage of $83.1 \pm 0.5 \%$ and $79.2 \pm 0.4 \%$ for MFCs operated at $40^{\circ} \mathrm{C}$ and $55^{\circ} \mathrm{C}$, respectively. This scenario can be explained by the fact that there was very little mesophilic anaerobic bacteria growth which therefore inhibited the oxidation of organic matter found in the wastewater. Likewise, COD removal percentage were less effective by $11.04 \pm 0.3 \%$ and $9.30 \pm 0.5 \%$ when operated at $15^{\circ} \mathrm{C}$ and $20^{\circ} \mathrm{C}$, respectively which
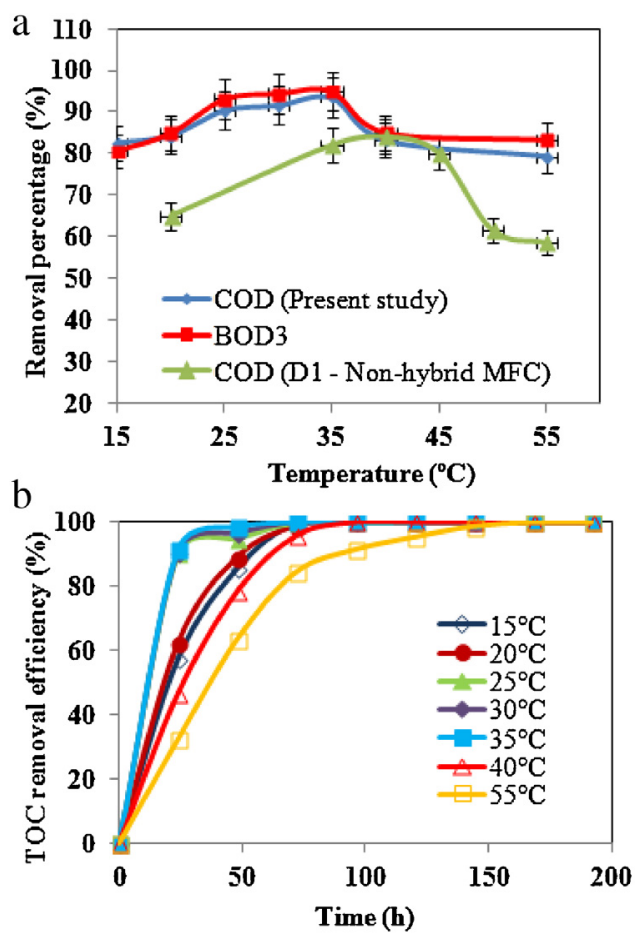

Fig. 2. (a) COD and BOD removal percentage at various operating temperature and (b) TOC removal efficiency over time. was mainly due to the lower degradation rate of influent organic matter at lower temperatures. Noted that the optimum operating temperature for effective COD removal in the present study was found to be at $\sim 35^{\circ} \mathrm{C}$ which is different as compared to the previous study done in a non-hybrid dual chamber $\operatorname{MFC}\left(D_{1}\right)$ where the maximum COD removal reported was $84 \%$ when operated at $40{ }^{\circ} \mathrm{C}$ [43]. This may be due to the poor adsorption performance in the MFC-adsorption hybrid system when operated at elevated temperature $\left(40^{\circ} \mathrm{C}\right.$ and above). As shown in Fig. 2a, the COD removal percentage gradient in between $15^{\circ} \mathrm{C}$ and $35^{\circ} \mathrm{C}$ in a hybrid system was $0.5889 \% \mathrm{C}^{-1}$ as compared to $1.4467 \% \mathrm{C}^{-1}$ in $\mathrm{D}_{1}$ (nonhybrid MFC). This scenario proved that the pollutants removal performance of the hybrid system was less sensitive to the changes of operating temperatures. Likewise, when the hybrid system was operated at elevated temperatures, the gradient of COD removal percentage was $0.2626 \% \mathrm{C}^{-1}$ as compared to $1.6800 \% \mathrm{C}^{-1}$ for $\mathrm{D}_{1}$. This phenomenon had demonstrated the importance of the MFCadsorption hybrid system over the standalone MFC where the integrated system had proved a tremendous stability over a wide range of operating temperatures in terms of COD removal where the performance were not much affected by the temperatures. This is mainly due to the sorption characteristics and large surface area of the GAC in the anode chamber adopted in the present study which has the ability in removing the organic compounds from the substrate. Recently, a dual chamber MFC with graphite granules adsorption hybrid system had demonstrated removal of $29.49 \%$ of COD when operated at $30^{\circ} \mathrm{C}[44]$. The COD removal efficiency was however less as compared to present study due to the fact that the surface area of the graphite granules used was only $35.75 \mathrm{~m}^{2} / \mathrm{g}$, $96.4 \%$ lower compared to the surface area of the GAC used in the present study.

At the moment, there are no studies done to understand the removal of BOD with MFC-adsorption hybrid system at various operating temperature. Therefore, in the present study, the BOD removal percentage was understood and presented in Fig. 2a. In the previous study done with MFC-adsorption hybrid system at $25^{\circ} \mathrm{C}$, a BOD removal of $93.1 \pm 0.5 \%$ was achieved [32]. However, in the present study, the highest BOD removal percentage recorded was $95.0 \pm 0.3 \%$ at $35^{\circ} \mathrm{C}$, followed by $94.4 \pm 0.5 \%$ at $30^{\circ} \mathrm{C}$ which was therefore able to achieve the stringent effluent discharge requirement set by the DOE for the BOD parameter, where the final BOD achieved was $11.65 \mathrm{mg} / \mathrm{l}$ and $12.9 \mathrm{mg} / \mathrm{l}$, respectively. In comparison to the previous study done in a non-hybrid semicontinuous air-cathode MFC, such system was only able to remove $77 \%$ of the BOD from landfill leachate [45]. The operating temperature was however not mentioned by the authors. Nevertheless, by comparing the BOD removal efficiency of these two different MFCs, it can be observed that integration of adsorption system to the MFC is an added advantage to the overall BOD removal performance.

Overall, it can be observed that regardless of MFCs operating temperature, the MFC-adsorption hybrid system has the ability to remove the entire TOC present in the wastewater (Fig. 2b). Tremendous TOC removals can be observed in the first $19 \mathrm{~h}$ of operation for MFCs operated in the range of $25^{\circ} \mathrm{C}$ and $35^{\circ} \mathrm{C}$ with removal of at least $90 \%$ and above. In the subsequent $24 \mathrm{~h}$, at least $95 \%$ of TOC were removed from the substrate and achieved $100 \%$ of removal after operated in the MFCs for $67 \mathrm{~h}$. For MFCs operated at temperature below $25^{\circ} \mathrm{C}$, a removal of $57.5 \pm 0.8 \%$ and $62.3 \pm 0.3 \%$ was achieved at $15^{\circ} \mathrm{C}$ and $20^{\circ} \mathrm{C}$ in the first $19 \mathrm{~h}$ and complete removal was achieved after $67 \mathrm{~h}$ of operation for both cases. For MFCs operated at $40^{\circ} \mathrm{C}$ and $55^{\circ} \mathrm{C}$, the TOC removal rate were slower as compared to other operating temperatures where complete TOC removals were only achieved after $91 \mathrm{~h}$ and $115 \mathrm{~h}$ of operation, respectively. A non-hybrid dual chamber MFC was only able to remove up to the maximum of $85 \%$ of TOC after $96 \mathrm{~h}$ of 
operation [46]. On the other hand, dual reactor systems were fabricated with a single chamber MFC as a low-voltage power source to simultaneously accomplish hydrogen peroxide generation and iron (II) release for the Fenton reaction and such configuration was able to achieve $75 \pm 2 \%$ TOC removal at $25^{\circ} \mathrm{C}$ [47]. Thus, in the present study, the great superiority of integrating adsorption system to MFC can be observed where TOC can be removed completely at any operating temperatures.

In the previous study, the removal efficiency for TS, TSS and TVS achieved in the same system was $35.0 \pm 0.3 \%, 96.9 \pm 0.2 \%$ and $89.0 \pm 0.2 \%$, respectively when operated at $25^{\circ} \mathrm{C}[32]$. The removal percentage of TS, TSS and TVS at various operating temperature is as shown in Fig. 3a. The optimum operating temperature for TSS removal was found to be at $35^{\circ} \mathrm{C}$ with removal percentage of $98.0 \pm 0.6 \%$. However, for TVS removal, the optimum performance was found to be at $30^{\circ} \mathrm{C}$ with removal percentage of $90.7 \pm 0.4 \%$, followed by $89.5 \pm 0.6 \%$ at $35^{\circ} \mathrm{C}$. For TS removal, the performance was generally about $20-40 \%$ lower as compared to TSS and TVS removals where the maximum removal was found to be at $35^{\circ} \mathrm{C}$ with removal percentage of $41.4 \pm 0.4 \%$. Optimum temperatures for solids removal were typically ranged in between $30^{\circ} \mathrm{C}$ and $35^{\circ} \mathrm{C}$, which can be explained by the fact that the MFCs anaerobic anode chamber has better tendency to reduce solids production at such conditions, where the bacterial biomass production by the MFCs system are much lower due to the anaerobic environment. A $90 \mathrm{~L}$ baffled non-hybrid microbial fuel cell stacked by five stacked modules was fabricated in the previous study for brewery wastewater treatment at ambient temperature and such system was able to remove SS as much as $86.3 \%$ which was about $10 \%$ less as compared to the current study [48]. Nevertheless, in comparison to another study done with MFC integrated with membrane bioreactor (MBR), such system was able to remove the entire SS present in the wastewater [9]. Therefore, in terms of solids removal, MFC-MBR hybrid system may be a better option in comparison to MFC-adsorption hybrid system because membrane type of unit operation has better solids rejection rate as compared to adsorption system.
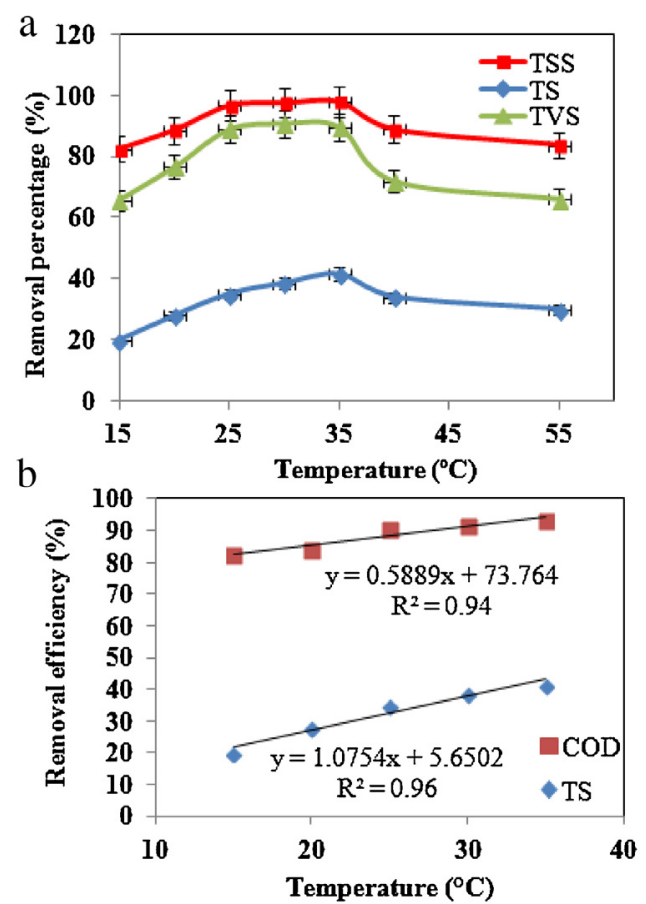

Fig. 3. (a) TS, TSS and TVS removal percentage at various operating temperature and (b) COD and TS removal efficiency as a function of temperature.
On top of that, we had discovered that there was a linear relationship between operating temperature and pollutants removal efficiency (Fig. 3b) at a rate of $0.5889 \% \mathrm{C}^{-1}$ with regression $\left(R^{2}\right)$ of 0.94 for COD removal and $1.0754 \% C^{-1}$ with regression $\left(R^{2}\right)$ of 0.96 for TS removal. The removal for these two pollutants as a function of operating temperature were only applicable for operating temperatures ranging from $15^{\circ} \mathrm{C}$ to $35^{\circ} \mathrm{C}$. In chemistry and biochemistry, the rate of change of a biological or chemical system as a consequence of the temperature by $10^{\circ} \mathrm{C}$ is defined as below:

$Q_{10}=\left(\frac{R_{2}}{R_{1}}\right)^{10 /\left(T_{2}-T_{1}\right)}$

Where $Q_{10}$ is the temperature coefficient, $R_{1}$ is the removal rate at temperature $T_{1}$ (where $T_{1}<T_{2}$ ), $R_{2}$ is the removal rate at $T_{2}$ (where $T_{2}>T_{1}$ ), $T_{1}$ is the temperature at which the removal rate $R_{1}$ is measured (where $T_{1}<T_{2}$ ) and $T_{2}$ is the temperature at which the removal rate $R_{2}$ is measured (where $T_{2}>T_{1}$ ) [49]. Typically, $Q_{10}$ value should fall in between 1 and 3 [50]. The COD and TS removal efficiency was taken as a measure of the rate of the electrochemical processes happening in the MFC-adsorption hybrid system and the temperature coefficient was calculated. It can be observed that the $Q_{10}$ relationship between COD and TS removal efficiency with temperature was 1.06 and 1.45 , respectively between $15^{\circ} \mathrm{C}$ and $35^{\circ} \mathrm{C}$. The linear function of temperature on COD and TS in Fig. $3 \mathrm{~b}$ were showing positive trends because the pollutants removal rate increased as a function of operating temperatures. The optimum operating temperatures can be seen to be $\sim 25-35^{\circ} \mathrm{C}$ which is about the temperature of the POME $\left(\sim 30-35^{\circ} \mathrm{C}\right)$ when obtained freshly from the original source. Therefore, MFC-adsorption hybrid system can be ideally implemented in tropical countries where the tropical temperature of $30-35^{\circ} \mathrm{C}$ is very close to the optimum operating temperature.

\subsection{Color, turbidity, $\mathrm{NH}_{3}-\mathrm{N}$ and $\mathrm{TN}$ removals}

POME is generally associated with dark brown color. The presence of organic compounds such as anthocyanin and carotene pigment that were extracted from fresh fruit bunches in the sterilization process imparts this persistent color to wastewater [33]. Therefore, it is crucial for decolorization of POME to happen before it is suitable to be discharged to the river. In order to achieve this, the effect of temperature on color removal was investigated in order to find the optimum operating temperature for the removal. In the previous study done in the same MFC-adsorption hybrid system, a removal of $98.1 \pm 0.3 \%$ was achieved when operated at temperature of $25 \pm 1{ }^{\circ} \mathrm{C}$ [32]. In the present study, it was discovered that there was not much changes on the decolorization when operated in between $15^{\circ} \mathrm{C}$ and $35^{\circ} \mathrm{C}$ (Fig. 4). Maximum color removal was achieved at $25^{\circ} \mathrm{C}$ and the decolorization performance were about $7-8 \%$ lower than optimum temperature when operated at elevated temperatures $\left(>40^{\circ} \mathrm{C}\right)$. Such behavior can be attributed by the fact that most of the color removals were responsible by the adsorption system in the MFC system where adsorption process was more effective at lower temperatures. The performance of color removal in the current MFC-adsorption hybrid system was typically attractive as compared to the removal efficiency of a nonhybrid air cathode MFC operated at $29 \pm 2{ }^{\circ} \mathrm{C}$ where the removal percentage recorded was only $31.67 \%$ for distillery wastewater [52]. Therefore, adsorption system played a crucial role in removing majority of the color present in the wastewater.

Turbidity in the wastewater is typically contributed by the presence of the suspended solids. From Fig. 4a, optimum temperature for effective turbidity removal was found to be at $30^{\circ} \mathrm{C}$ with the removal percentage of $98.00 \pm 0.7$ as compared to 

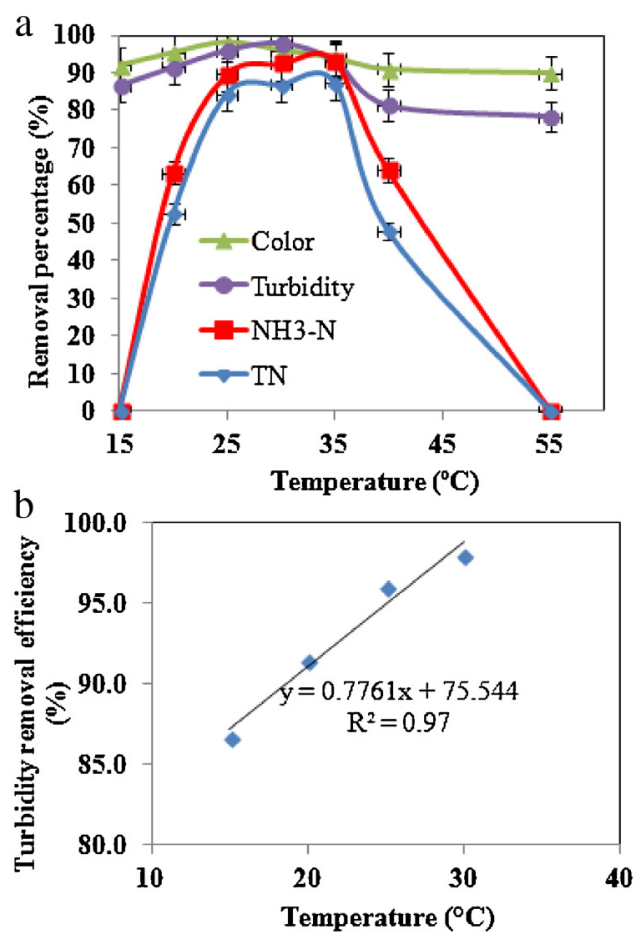

Fig. 4. (a) Color, turbidity, $\mathrm{NH}_{3}-\mathrm{N}$ and $\mathrm{TN}$ removal percentage at various operating temperature and (b) turbidity as removal efficiency as a function of temperature.

$96.0 \pm 0.4 \%$ when operated at $25^{\circ} \mathrm{C}$ in the previous study [32]. As compared to the performance of the fuel cell which incorporated biocatalyst in the system and operated at ambient temperature $\left(28 \pm 2{ }^{\circ} \mathrm{C}\right)$ without the application of GAC [53], such system was able to remove turbidity maximum up to $96 \%$, which was $2 \%$ less as compared to the MFC system in the current study. The operating temperature was found to be proportional to the turbidity removal efficiency at a rate of $0.7761 \% \mathrm{C}^{-1}$ with regression $\left(\mathrm{R}^{2}\right)$ of 0.97 . Such relationship was only applicable for operating temperature range in between $15^{\circ} \mathrm{C}$ and $30^{\circ} \mathrm{C}$. For temperature more than $35^{\circ} \mathrm{C}$ and above, the performance started to decrease from $93.2 \pm 0.5 \%$ at $35^{\circ} \mathrm{C}-29.9 \pm 0.3$ at $55^{\circ} \mathrm{C}$. The temperature coefficient $\left(\mathrm{Q}_{10}\right)$ is found to be 1.09 between $15^{\circ} \mathrm{C}$ and $30^{\circ} \mathrm{C}$. The linear relationship in between turbidity and operating temperature was showing positive trend because turbidity removal rate increased as a function of operating temperature with maximum removal observed at $30^{\circ} \mathrm{C}$.

The MFC-adsorption hybrid system has the ability to remove $\mathrm{NH}_{3}-\mathrm{N}$ and $\mathrm{TN}$ as much as $89.6 \pm 0.5 \%$ and $84.3 \pm 0.4 \%$, respectively at the temperature of $25 \pm 1{ }^{\circ} \mathrm{C}$ as reported in the previous study [32]. In the present study, it can be observed that the optimum temperature for $\mathrm{NH}_{3}-\mathrm{N}$ and $\mathrm{TN}$ removals was at $35^{\circ} \mathrm{C}$ with removal efficiency of $93.3 \pm 0.8 \%$ and $87.3 \pm 0.7 \%$, respectively (Fig. 4a). Such scenario may be due to the effectiveness of the ammonium ion $\left(\mathrm{NH}^{+}\right)$migration in the anode chamber to the cathode which might eventually become nitrogen via further nitrification and denitrification reactions in the air cathode compartment under the optimum temperature. Similar phenomenon can also be observed in a non-hybrid dual chamber MFC operated at room temperature $\left(\sim 23^{\circ} \mathrm{C}\right)$ where a total of $30.4 \%$ of the $\mathrm{NH}_{4}^{+}$migrated through the PEM to the cathode chamber for nitrification [54]. Since there was an effective removal of $\mathrm{NH}_{3}-\mathrm{N}$ in the anode chamber when operated at $35^{\circ} \mathrm{C}$, TN concentration was greatly affected as well because $\mathrm{NH}_{3}-\mathrm{N}$ was one of the component measured in $\mathrm{TN}$, on top of other organic nitrogen, nitrate nitrogen and nitrite nitrogen presented in the POME. In the previous study, an integration of dual chamber membrane-less MFC with adsorption hybrid system was fabricated with the anode chamber filled with graphite granules and tested for $\mathrm{NH}_{3}-\mathrm{N}$ removal in POME [25]. Such system was able to demonstrate about $76 \%$ of $\mathrm{NH}_{3}-\mathrm{N}$ removal after operated at room temperature for approximately 33 days. The performance of the MFC system in the present study has however demonstrated a better performance in $\mathrm{NH}_{3}-\mathrm{N}$ removal which may be due to the difference in terms of anode fillers where GAC has better capability in removing $\mathrm{NH}_{3}-\mathrm{N}$ as compared to graphite granules due to the high surface area of GAC. Besides, the configuration of single and double chambers MFC may have affected the $\mathrm{NH}_{4}^{+}$migration where the movement of $\mathrm{NH}_{4}^{+}$to the cathode compartment should be more effective in the single chamber MFC due to the wide cathode surface area.

\subsection{Bioenergy generation}

All the MFC-adsorption hybrid system were inoculated at $25 \pm 1{ }^{\circ} \mathrm{C}$ until a stable voltage was achieved before switching them to respective operating temperatures of $15^{\circ} \mathrm{C}, 20^{\circ} \mathrm{C}, 25^{\circ} \mathrm{C}, 30^{\circ} \mathrm{C}$, $35^{\circ} \mathrm{C}, 40^{\circ} \mathrm{C}$ and $55^{\circ} \mathrm{C}$ in the closed-loop mode. At the first few hours of inoculation, the voltage generated was rather low but was however, started to demonstrate a steady increase after $100 \mathrm{~h}$ of inoculation in the MFCs. The low voltage generation during the first few hours might be due to the anode biofilm which were yet to be established and therefore limit the electron transfer to the electrodes. The MFCs were fed with fresh POME in a closed-loop mode after $200 \mathrm{~h}$ of inoculation at the rate of $6.12 \mathrm{Lh}^{-1}$ and COD loading of $884 \pm 3 \mathrm{mg} \mathrm{L}^{-1}$.

In the previous study, an operating temperature of $25 \pm 1^{\circ} \mathrm{C}$ was tested in the same MFC-adsorption hybrid system, fabricated from low cost, local ceramic material in a closed-loop mode and it had been reported that an average voltage of $106 \mathrm{mV}$ was achieved after $171 \mathrm{~h}$ of operation [32]. In the present studies, the performance of the voltage generated from such system was further investigated at other operating temperatures of $15^{\circ} \mathrm{C}$, $20^{\circ} \mathrm{C}, 30^{\circ} \mathrm{C}, 35^{\circ} \mathrm{C}, 40^{\circ} \mathrm{C}$ and $55^{\circ} \mathrm{C}$ and results were as shown in Fig. $5 \mathrm{a}$.

From Fig. 5a, it can be observed that the voltage were moving downtrend especially for MFCs operated at temperatures of $15^{\circ} \mathrm{C}$, $20^{\circ} \mathrm{C}, 40^{\circ} \mathrm{C}$ and $55^{\circ} \mathrm{C}$ until a stable voltage was achieved. The average voltage recorded were $71.74 \pm 6.4 \mathrm{mV}, 92.48 \pm 4.3 \mathrm{mV}$, $64.45 \pm 9.1 \mathrm{mV}$ and $62.61 \pm 11.5 \mathrm{mV}$, respectively. The voltage generations at these operating temperatures were however 20$45 \%$ lower as compared to the baseline studies done at $25^{\circ} \mathrm{C}$. The decreased of voltage generation at lower temperature may be due to inactive microbial activities [55]. Therefore, such phenomenon may affect the substrate utilization rate which therefore minimal substrate is being converted into bio-energy. Low voltage generation at elevated operating temperatures $\left(>40^{\circ} \mathrm{C}\right)$ may be due to the denaturation of enzyme which therefore, lead to low voltage generation as a result of poor electrons transfer to the electrode [37]. On top of that, when bacteria was exposed to high temperatures continuously, important elements presented in the cell such as proteins, nucleic acids or other temperature-sensitive matter may suffered an irreversible damage which therefore affect the cell function.

Operating temperatures of $30^{\circ} \mathrm{C}$ and $35^{\circ} \mathrm{C}$ had however achieved a more satisfactory magnitude of voltage generation with an average of $115.68 \pm 8.2 \mathrm{mV}$ and $125.69 \pm 9.1 \mathrm{mV}$, respectively. Such phenomenon may be due to the increase in biomass growth and substrate utilization as the temperature increases which therefore, improve the microbial activities and bacterial attachment on the electrode [56]. Thus, electrons could be 


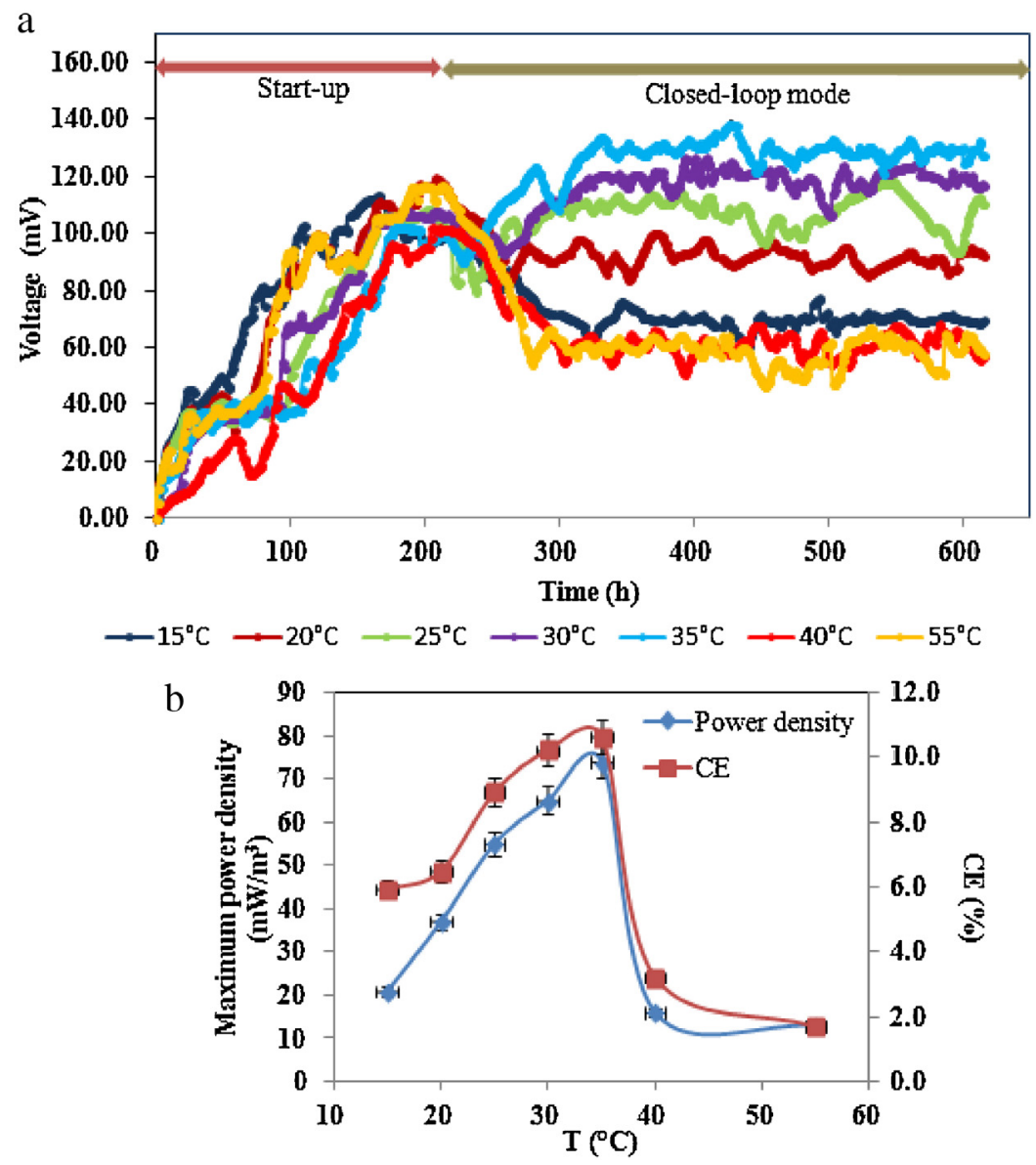

Fig. 5. (a) Voltage generation over $600 \mathrm{~h}$ of operation, (b) maximum power density and coulombic efficiency (CE) as a function of operating temperature.

transferred effectively to the anode electrodes which then helped to increase the voltage generation.

In the previous study, the maximum power density and coulombic efficiency (CE) was approximately $55 \mathrm{~mW} / \mathrm{m}^{3}$ and $8.94 \pm 0.3 \%$ when operated at $25^{\circ} \mathrm{C}[32]$. The same MFC-adsorption hybrid was tested for other operating temperature of $15^{\circ} \mathrm{C}, 20^{\circ} \mathrm{C}$, $30^{\circ} \mathrm{C}, 35^{\circ} \mathrm{C}, 40^{\circ} \mathrm{C}$ and $55^{\circ} \mathrm{C}$ and the findings were tabulated in Fig. 5b. The power density and CE were calculated based on Eqs. (1) and (2). Generally, polarization curves were measured when the cell voltage become relatively stable which was after $300 \mathrm{~h}$. The highest power density and CE were achieved when MFC was operated at $35^{\circ} \mathrm{C}$ with the results of $74 \pm 6 \mathrm{~mW} / \mathrm{m}^{3}$ and $10.65 \pm 0.5 \%$, respectively. Generally, the performance at $35^{\circ} \mathrm{C}$ was found better as compared to the MFC-adsorption hybrid system operated at $25^{\circ} \mathrm{C}$ which may be due to the fact that the biofilms grown at $35^{\circ} \mathrm{C}$ are more electrochemically active as compared to those grown at $25^{\circ} \mathrm{C}$ which in turn helps in the transfer of the electrons to the anode electrode.

\subsection{Comparison with other MFC-hybrid systems}

MFC integrated with any unit operations or processes have the privilege of combining the advantages of each unit as compared to the standalone MFC [7]. Several studies have been done on MFChybrid system recently and a comprehensive comparison of these systems were done in terms of operating temperature, pollutant removal efficiency, MFC design, source of inocula, substrate and economics feasibility and presented in Table 3. Integrating MFC with membrane bioreactor (MBR) has been a trend in the recent years where it can be observed that such system is able to remove
COD with about $90 \%$ or more when integrated with tubular membrane bioreactor (TMBR) $[9,10]$ and anaerobic fluidized bed membrane bioreactor (AFMBR) [57]. Besides, the effluent SS concentration was nearly nil with $\mathrm{NH}_{3}-\mathrm{N}$ removal of more than 93.6\% when operated at room temperatures ranging in between $14^{\circ} \mathrm{C}$ and $25^{\circ} \mathrm{C}$. There is no doubt that MFC-MBR hybrid system has the ability in removing organics and solids from the wastewater. Nevertheless, the efficiency of such system in removing other pollutants such as color, turbidity and nutrients are not reported. Besides, majority of the MFC-MBR hybrid system requires aeration system which therefore increases the operating cost and makes it impractical to scale-up. Even though no aeration system was involved in the MFC-AFMBR hybrid system, the adoption of expensive platinum $(\mathrm{Pt})$ catalyst could be a major concern in terms of economic feasibility.

MFC integrated with adsorption can be an ideal combined system. On top of the typical biological electrochemical processes that normally take place in an MFC, physicochemical processes from the activated carbon happen simultaneously [32]. The activated carbon has the ability to remove a wide range of pollutants from the wastewater which may not be able to remove through the standalone MFC system. Therefore, any integration of MFC system with adsorption unit processes can be a great hybrid system to improve the wastewater quality besides deriving bioenergy from the system. Besides, the high surface area of the activated carbon can be a great platform for bacterial attachment for a more efficient electron transfer to the anode electron which improves the bio-energy generation. From Table 3, MFC-adsorption hybrid system in the dual chamber MFC [58] has reported a lower COD and color removals when operated at $30^{\circ} \mathrm{C}$ as compared 
Table 3

Performance of MFC-hybrid system under different operating temperatures ranging from $25^{\circ} \mathrm{C}$ to $35^{\circ} \mathrm{C}$.

\begin{tabular}{|c|c|c|c|c|c|}
\hline & $\begin{array}{l}\text { Dual chamber MFC- } \\
\text { adsorption [58] }\end{array}$ & $\begin{array}{l}\text { Two-stage MFC- } \\
\text { immobilized } \\
\text { biological aerated } \\
\text { filter (I-BAF) [25] }\end{array}$ & $\begin{array}{l}\text { Two stage MFC-anaerobic } \\
\text { fluidized bed membrane } \\
\text { bioreactor (AFMBR) [57] }\end{array}$ & MFC-adsorption [32] & MFC-adsorption (Present work) \\
\hline $\begin{array}{l}\text { Operating } \\
\text { temperature }\end{array}$ & $30^{\circ} \mathrm{C}$ & $35^{\circ} \mathrm{C}$ & $\sim 25^{\circ} \mathrm{C}$ & $25^{\circ} \mathrm{C}$ & $35^{\circ} \mathrm{C}$ \\
\hline $\begin{array}{l}\text { Pollutants } \\
\text { removed }\end{array}$ & $\begin{array}{l}\text { COD - 71\% (anode), } \\
76 \% \text { (cathode) } \\
\text { Color }-73 \% \text { (anode), } \\
77 \% \text { (cathode) }\end{array}$ & $\begin{array}{l}\mathrm{COD}-96.5 \% \\
\mathrm{NH}_{3}-\mathrm{N}-93.6 \%\end{array}$ & $\begin{array}{l}\text { COD }-92.5 \% \\
\text { TSS }-\sim 100 \%\end{array}$ & $\begin{array}{l}\text { COD }-90.5 \\
\mathrm{BOD}_{3}-93.1 \\
\text { TOC }-100 \% \\
\text { TSS }-96.9 \\
\text { TVS }-89.0 \\
\text { TS }-35.0 \\
\text { Color }-98.1 \\
\mathrm{NH}_{3}-\mathrm{N}-89.6 \\
\text { TN }-84.3 \\
\text { Turbidity }-96.0\end{array}$ & $\begin{array}{l}\text { COD }-93.6 \\
\mathrm{BOD}_{3}-95.0 \\
\text { TOC }-100 \% \\
\text { TSS }-98.0 \\
\text { TVS }-89.5 \\
\text { TS }-41.4 \\
\text { Color }-94.0 \\
\mathrm{NH}_{3}-\mathrm{N}-93.3 \\
\text { TN }-87.3 \\
\text { Turbidity }-93.2\end{array}$ \\
\hline Anode & GAC and graphite rod & $\begin{array}{l}\text { MFC } 1 \text { - Graphite } \\
\text { granules and } \\
\text { graphite rod } \\
\text { MFC } 2 \text { - Carbon } \\
\text { fiber felt and copper } \\
\text { wire }\end{array}$ & GFB and titanium core wire & GAC and GFB & GAC and GFB \\
\hline Cathode & GAC and graphite rod & $\begin{array}{l}\text { Lead oxide electrode } \\
\text { with copper wire }\end{array}$ & $\begin{array}{l}\text { Carbon cloth with platinum (Pt) } \\
\text { catalyst on water side and four } \\
\text { polytetrafluoroethylene (PTFE) } \\
\text { layers on the air side }\end{array}$ & ACFF and copper wire & ACFF and copper wire \\
\hline PEM & Glass wool & No membrane & Two layers of textile separator & Ceramic pot & Ceramic pot \\
\hline $\begin{array}{r}\text { Source of } \\
\text { inocula }\end{array}$ & $\begin{array}{l}\text { Aerobic sludge from } \\
\text { dye wastewater plant }\end{array}$ & $\begin{array}{l}\text { Anaerobic digestion } \\
\text { and activated sludge } \\
\text { from sewage plant }\end{array}$ & $\begin{array}{l}\text { Domestic wastewater from } \\
\text { primary clarifier of wastewater } \\
\text { plant }\end{array}$ & POME & POME \\
\hline Substrate & Dye wastewater & POME & Domestic wastewater & POME & POME \\
\hline $\begin{array}{l}\text { Other } \\
\text { characteristic }\end{array}$ & $\begin{array}{l}\text { Low investment cost, } \\
\text { chigh operating cost } \\
\text { due to aeration. Two- } \\
\text { chambers MFC. }\end{array}$ & $\begin{array}{l}\text { Low investment } \\
\text { cost, high operating } \\
\text { cost due to aeration } \\
\text { in both MFCs. }\end{array}$ & $\begin{array}{l}\text { High investment cost due to Pt } \\
\text { catalyst is expensive, low } \\
\text { operating cost due to no aeration } \\
\text { involve. }\end{array}$ & $\begin{array}{l}\text { Low investment cost, low } \\
\text { operating cost due to no aeration } \\
\text { and no expensive catalyst involve. } \\
\text { Single chamber MFC. }\end{array}$ & $\begin{array}{l}\text { Low investment cost, low } \\
\text { operating cost due to no aeration } \\
\text { and no expensive catalyst involve. } \\
\text { Single chamber MFC. }\end{array}$ \\
\hline
\end{tabular}

to the single chamber, air-cathode MFC-adsorption hybrid system when operated at $25 \pm 1{ }^{\circ} \mathrm{C}$ [32] and $35 \pm 1^{\circ} \mathrm{C}$ (present study). Nevertheless, dual chamber MFC-adsorption hybrid system involves aeration system which can be very challenging in terms of scaling up and operating cost. Basically, the single chamber, aircathode MFC-adsorption hybrid system operated at $35 \pm 1{ }^{\circ} \mathrm{C}$ had generally demonstrated better pollutants removals as compared to the one operated at $25 \pm 1{ }^{\circ} \mathrm{C}$ except for color and turbidity. POME for these studies was taken from the second anaerobic pond where the substrate temperature can range in between $30^{\circ} \mathrm{C}$ and $35^{\circ} \mathrm{C}$. It is therefore practical for MFC-adsorption hybrid system with POME as the substrate to run at $35^{\circ} \mathrm{C}$ for optimal pollutants removal where no further temperature adjustment is needed. Besides, such system does not involve the application of expensive catalyst as well as aeration system which makes it possible for scale-up application.

MFC integrated with immobilized biological aerated filter (IBAF) operated at $35 \pm 1{ }^{\circ} \mathrm{C}$ with POME as the substrate had generally demonstrated $\mathrm{COD}$ and $\mathrm{NH}_{3}-\mathrm{N}$ removal which was almost comparable with the MFC-adsorption hybrid system operated at the same operating temperature [25]. Nevertheless, such removals through MFC-I-BAF hybrid system can only be achieved after operated for about 33 days as compared to MFCadsorption hybrid system where the same removals can be achieved within $\sim 6$ days of operation. Even though the MFC-IBAF hybrid system was fabricated with cost effective materials, such system involved two aeration units which was consider not so practical for scale-up application.

\section{Conclusions}

In this work, we have presented findings from MFC-adsorption hybrid system, which was operated at six different operating temperatures $\left(15^{\circ} \mathrm{C}, 20^{\circ} \mathrm{C}, 30^{\circ} \mathrm{C}, 35^{\circ} \mathrm{C}, 40^{\circ} \mathrm{C}\right.$ and $\left.55^{\circ} \mathrm{C}\right)$ and the performance were compared to the previous work done in terms of $\mathrm{pH}$ profiles, bioelectricity generation, organics, solids, nutrients, color and turbidity removal. In the present study, it can be observed that the pollutants removal efficiency for POME with MFC-adsorption hybrid system is very much affected by the operating temperatures. The optimum temperature was found to be at $35^{\circ} \mathrm{C}$ where such condition had demonstrated maximum removal of COD, BOD, TSS, TS, TN, $\mathrm{NH}_{3}-\mathrm{N}$ and TOC. Besides, the maximum power density achieved was $74 \pm 6 \mathrm{~mW} / \mathrm{m}^{3}$ with CE of $10.65 \pm 0.5 \%$ when operated at $35^{\circ} \mathrm{C}$. Other important findings from the present study include:

- Generally, MFC-adsorption hybrid system had demonstrated better pollutants removal efficiency as compared to standalone and other types of MFCs. This may be due to the application of adsorption system in the MFC which further improved on the wastewater quality.

- The performance of COD removal efficiency in a MFC-adsorption hybrid system was less sensitive to the changes of the operating temperatures where the performance was found to be 80-94\% when operated in between 15 and $55^{\circ} \mathrm{C}$ as compared to $60-84 \%$ when operated with standalone MFC in between 20 and $55^{\circ} \mathrm{C}$.

Such system is feasible and ideally to be implemented in tropical countries where the tropical temperature of $30-35^{\circ} \mathrm{C}$ is very close to the optimum operating temperature as indicated in the current study.

\section{Acknowledgements}

This present study was supported by the Ministry of Higher Education (MOHE), Malaysia under the Exploratory Research 
Grant Scheme (ERGS), Contract No: EGRS/STG07(01)/1006/2013 (13) and Dana Pelajar PhD (DPP) Grant No.F02(DPP29)/1244/2015 (04). The first author was initially supported fully by the ERGS grant and recently obtained her prestige MOHE's MyPhD scholarship and DPP grant. The authors would like to thank all staff for their continuous encouragements throughout this project.

\section{References}

[1] B. Virdis, K. Rabaey, Z. Yuan, J. Keller, Microbial fuel cells for simultaneous carbon and nitrogen removal, Water Res. 42 (2008) 3013-3024.

[2] M.O. Abdullah, Applied Energy: An Introduction, CRC Press, Florida, 2013.

[3] S. Wu, H. Li, X. Zhou, P. Liang, X. Zhang, Y. Jiang, X. Huang, A novel pilot-scale stacked microbial fuel cell for efficient electricity generation and wastewater treatment, Water Res. 98 (2016) 396-403.

[4] V.J. Watson, B.E. Logan, Analysis of polarization methods for elimination of power overshoot in microbial fuel cells, Electrochem. Commun. 13 (2011) 54 56.

[5] K.Y. Lee, W.S. Ryu, S.I. Cho, K.H. Lim, Comparative study on power generation of dual-cathode microbial fuel cell according to polarization methods, Water Res. 84 (2015) 43-48.

[6] B. Min, J. Kim, S. Oh, J.M. Regan, B.E. Logan, Electricity generation from swine wastewater using microbial fuel cells, Water Res. 39 (2005) 4961-4968.

[7] P.F. Tee, M.O. Abdullah, I.A.W. Tan, N.K.A. Rashid, M.A.M. Amin, C. NolascoHipolito, K. Bujang, Review on hybrid energy systems for wastewater treatment and bio-energy production, Renew. Sustain. Energy Rev. 54 (2016) $235-246$.

[8] S. Gajaraj, Z. Hu, Integration of microbial fuel cell techniques into activated sludge wastewater treatment processes to improve nitrogen removal and reduce sludge production, Chemosphere 117 (2014) 151-157.

[9] J. Wang, Y. Zheng, H. Jia, H. Zhang, In situ investigation of processing property in combination with integration of microbial fuel cell and tubular membrane bioreactor, Bioresour. Technol. 149 (2013) 163-168.

[10] Y.P. Wang, X.W. Liu, W.W. Li, F. Li, Y.K. Wang, G.P. Sheng, R.J. Zeng, H.Q. Yu, A microbial fuel cell-membrane bioreactor integrated system for cost-effective wastewater treatment, Appl. Energy 98 (2012) 230-235.

[11] D. Hou, L. Lu, Z.J. Ren, Microbial fuel cells and osmotic membrane bioreactors have mutual benefits for wastewater treatment and energy production, Water Res. 98 (2016) 183-189.

[12] A.K. Yadav, P. Dash, A. Mohanty, R. Abbassi, B.K. Mishra, Performance assessment of innovative constructed wetland-microbial fuel cell for electricity production and dye removal, Ecol. Eng. 47 (2012) 126-131.

[13] E. Fernando, T. Keshavarz, G. Kyazze, K. Fonseka, Treatment of colour industry wastewaters with concomitant bioelectricity production in a sequential stacked mono-chamber microbial fuel cells-aerobic system, Environ. Technol. 37 (2016) 255-264.

[14] F. Zhang, Z. He, Integrated organic and nitrogen removal with electricity generation in a tubular dual- cathode microbial fuel cell, Process Biochem. 47 (2012) 2146-2151.

[15] X. Zhang, F. Zhu, L. Chen, Q. Zhao, G. Tao, Removal of ammonia nitrogen from wastewater using an aerobic cathode microbial fuel cell, Bioresour. Technol. 146 (2013) 161-168.

[16] T. Kim, J. An, H. Lee, J.K. Jang, I.S. Chang, pH-dependent ammonia removal pathways in microbial fuel cell system, Bioresour. Technol. 215 (2016) 290295.

[17] J. Li, C. Liu, Q. Liao, X. Zhu, D. Ye, Improved performance of a tubular microbial fuel cell with a composite anode of graphite fiber brush and graphite granules, Int. J. Hydrogen Energy 38 (2013) 15723-15729.

[18] X.W. Liu, Y.P. Wang, Y.X. Huang, X.F. Sun, G.P. Sheng, R.J. Zeng, F. Li, F. Dong, S.G Wang, Z.H. Tong, H.O. Yu, Integration of a microbial fuel cell with activated sludge process for energy-saving wastewater treatment: taking a sequencing batch reactor as an example, Biotechnol. Bioeng. 108 (2011) 1260-1267.

[19] F. Zhang, Z. Ge, J. Grimaud, J. Hurst, Z. He, In situ investigation of tubular microbial fuel cells deployed in an aeration tank at a municipal wastewater treatment plant, Bioresour. Technol. 136 (2013) 316-321.

[20] R.J. Weld, R. Singh, Functional stability of a hybrid anaerobic digester/microbial fuel cell system treating municipal wastewater, Bioresour. Technol. 102 (2011) $842-847$.

[21] Y. Sharma, B. Li, Optimizing energy harvest in wastewater treatment by combining anaerobic hydrogen producing biofermentor (HPB) and microbial fuel cell (MFC), Int. J. Hydrogen Energy 35 (2010) 3789-3797.

[22] W. Kong, Q. Guo, X. Wang, X. Yue, Electricity generation from wastewater using an anaerobic fluidized bed microbial fuel cell, Ind. Eng. Chem. Res 50 (2011) $12225-12232$.

[23] Y.L. Oon, S.A. Ong, L.N. Ho, Y.S. Wong, Y.S. Oon, H.K. Lehl, W.E. Thung, Hybrid system up-flow constructed wetland integrated with microbial fuel cell for simultaneous wastewater treatment and electricity generation, Bioresour. Technol. 186 (2015) 270-275.

[24] L. Ren, Y. Ahn, B.E. Logan, A two-stage microbial fuel cell and anaerobic fluidized bed membrane bioreactor (MFC-AFMBR) system for effective domestic wastewater treatment, Environ. Sci. Technol. 48 (2014) 4199-4206.
[25] J. Cheng, X. Zhu, J. Ni, A. Borthwick, Palm oil mill effluent treatment using a two-stage microbial fuel cells system integrated with immobilized biological aerated filters, Bioresour. Technol. 101 (2010) 2729-2734.

[26] I. Zekker, E. Rikmann, T. Tenno, L. Loorits, K. Kroon, H. Fritze, T. Tuomivirta, P. Vabamäe, M. Raudkivi, A. Mandel, S.S. Sergio, D.C. Rubin, T. Tenno, Nitric oxide for anammox recovery in a nitrite-inhibited deammonification system, Environ. Technol. 36 (2015) 2477-2487.

[27] I. Zekker, E. Rikmann, T. Tenno, K. Kroon, A. Seiman, L. Loorits, H. Fritze, T. Tuomivirta, P. Vabamäe, M. Raudkivi, A. Mandel, Start-up of low-temperature anammox in UASB from mesophilic yeast factory anaerobic tank inoculum, Environ. Technol. 36 (2015) 214-225.

[28] S. Cheng, D. Xing, B.E. Logan, Electricity generation of single-chamber microbial fuel cells at low temperatures, Biosens. Bioelectron. 26 (2011) 1913-1917.

[29] M.T. Madigan, J.M. Martinko, Brock Biology of Microorganisms, Pearson Prentice Hall, Upper Saddle River, New Jersey, 2006.

[30] A.N. Ghadge, M.M. Ghangrekar, Performance of low cost scalable air-cathode microbial fuel cell made from clayware separator using multiple electrodes, Bioresour. Technol. 182 (2015) 373-377.

[31] P. Chatterjee, M.M. Ghangrekar, Design of clayware separator-electrode assembly for treatment of wastewater in microbial fuel cells, Appl. Biochem. Biotechnol. 173 (2014) 378-390.

[32] P.F. Tee, M.O. Abdullah, I.A.W. Tan, N.K.A. Rashid, M.A.M. Amin, C. NolascoHipolito, K. Bujang, Performance evaluation of a hybrid system for efficient palm oil mill effluent treatment via an air-cathode, tubular upflow microbial fuel cell coupled with a granular activated carbon adsorption, Bioresour. Technol. 216 (2016) 478-485.

[33] X. Wang, Y.J. Feng, H. Lee, Electricity production from beer brewery wastewater using single chamber microbial fuel cell, Water Sci. Technol. 57 (2008) 1117-1121.

[34] H. Liu, S. Cheng, B.E. Logan, Power generation in fed-batch microbial fuel cells as a function of ionic strength temperature, and reactor configuration, Environ. Sci. Technol. 39 (2005) 5488-5493.

[35] Y. Ahn, B.E. Logan, Effectiveness of domestic wastewater treatment using microbial fuel cells at ambient and mesophilic temperatures, Bioresour. Technol. 101 (2010) 469-475.

[36] Y. Liu, V. Climent, A. Berna, J.M. Feliu, Effect of temperature on the catalytic ability of electrochemically active biofilm as anode catalyst in microbial fuel cells, Electroanalysis 23 (2011) 387-394.

[37] W. Kong, Q. Guo, X. Wang, X. Yue, Electricity generation from wastewater using an anaerobic fluidized bed microbial fuel cell, Ind. Eng. Chem. Res. 50 (2011) $12225-12232$

[38] A. Larrosa-Guerrero, K. Scott, I.M. Head, F. Mateo, A. Ginesta, C. Godinez, Effect of temperature on the performance of microbial fuel cells, Fuel 89 (2010) 3985-3994.

[39] G.S. Jadhav, M.M. Ghangrekar, Performance of microbial fuel cell subjected to variation in $\mathrm{pH}$ temperature, external load and substrate concentration, Bioresour. Technol. 100 (2009) 717-723.

[40] X. Zhang, P. Liang, J. Shi, J. Wei, X. Huang, Using a glass fiber separator in a single-chamber air-cathode microbial fuel cell shortens start-up time and improves anode performance at ambient and mesophilic temperatures, Bioresour. Technol. 130 (2013) 529-535.

[41] L. Daija, A. Selberg, E. Rikmann, I. Zekker, T. Tenno, T. Tenno, The influence of lower temperature, influent fluctuations and long retention time on the performance of an upflow mode laboratory-scale septic tank, Desalin. Water Treat. (2015) 1-9.

[42] S.A. Ong, K. Uchiyama, D. Inadama, K. Yamagiwa, Simultaneous removal of color, organic compounds and nutrients in azo dye-containing wastewater using up-flow constructed wetland, J. Hazard. Mater. 165 (2009) 696-703.

[43] M. Behera, S.S.R. Murthy, M.M. Ghangrekar, Effect of operating temperature on performance of microbial fuel cell, Water Sci. Technol. 64 (2011) 917-922.

[44] A. Asghar, A. Salihoudin, A. Aziz Abdul Raman, W. Mohd Ashri Wan Daud, Cathode modification to enhance the performance of in-situ fenton oxidation in microbial fuel cells, Environ. Prog. Sustain. Energy (2016), doi:http://dx.doi. org/10.1002/ep.12468.

[45] K. Ganesh, J.R. Jambeck, Treatment of landfill leachate using microbial fuel cells: alternative anodes and semi-continuous operation, Bioresour. Technol. 139 (2013) 383-387.

[46] X. Zhu, J. Ni, Simultaneous processes of electricity generation and pnitrophenol degradation in a microbial fuel cell, Electrochem. Commun. 11 (2009) 274-277.

[47] X. Zhu, B.E. Logan, Using single-chamber microbial fuel cells as renewable power sources of electro-fenton reactors for organic pollutant treatment, J. Hazard. Mater. 252 (2013) 198-203.

[48] Y. Dong, Y. Qu, W. He, Y. Du, J. Liu, X. Han, Y. Feng, A 90-liter stackable baffled microbial fuel cell for brewery wastewater treatment based on energy selfsufficient mode, Bioresour. Technol. 195 (2015) 66-72.

[49] I. Zekker, E. Rikmann, A. Mandel, K. Kroon, A. Seiman, J. Mihkelson, T. Tenno, T. Tenno, Step-wise temperature decreasing cultivates a biofilm with high nitrogen removal rates at $9 \mathrm{C}$ in short-term anammox biofilm tests, Environ. Technol. 37 (2016) 1933-1946.

[50] Y. Xiao, Modelling temperature-dependency in biology by generalizing temperature coefficient Q 10, Ecol. Modell. 127 (2000) 283-290.

[52] G. Mohanakrishna, S.V. Mohan, P.N. Sarma, Bio-electrochemical treatment of distillery wastewater in microbial fuel cell facilitating decolorization and desalination along with power generation, J. Hazard. Mater. 177 (2010) 487-494. 
[53] G. Velvizhi, S.V. Mohan, Biocatalyst behavior under self-induced electrogenic microenvironment in comparison with anaerobic treatment: evaluation with pharmaceutical wastewater for multi-pollutant removal, Bioresour. Technol. 102 (2011) 10784-10793.

[54] A. Sotres, M. Cerrillo, M. Viñas, A. Bonmatí, Nitrogen removal in a twochambered microbial fuel cell: establishment of a nitrifying-denitrifying microbial community on an intermittent aerated cathode, Chem. Eng. J. 284 (2016) 905-916.

[55] S.A. Patil, F. Harnisch, B. Kapadnis, U. Schröder, Electroactive mixed culture biofilms in microbial bioelectrochemical systems: the role of temperature for biofilm formation and performance, Biosens. Bioelectron. 26 (2010) 803-808.
[56] C.P.L. Grady Jr, G.T. Daigger, H.C. Lim, Rotating Biological Contactor. Biological Wastewater Treatment, Marcel Dekker, New York, 1999.

[57] L. Ren, Y. Ahn, B.E. Logan, A two-stage microbial fuel cell and anaerobic fluidized bed membrane bioreactor (MFC-AFMBR) system for effective domestic wastewater treatment, Environ. Sci. Technol. 48 (2014) 4199-4206.

[58] S. Kalathil, J. Lee, M.H. Cho, Granular activated carbon based microbial fuel cell for simultaneous decolorization of real dye wastewater and electricity generation, New Biotechnol. 29 (2011) 32-37. 